\title{
Coxの比例ハザードモデルを用いた 肺小細胞癌の予後因子の検討
}

\author{
Analysis of Prognostic Factors of Patients with Small Cell Lung Cancer \\ using Cox's Proportional Hazards Model
}

竹中雅彦・岩橋徳明・中野孝司・前田重一郎

相原信之・安室芳樹・波田寿一・東野一彌

\begin{abstract}
要旨：1978年から1991年までの間に, 兵庫医科大学第三内科に入院し, 多剤併用化学療法を施 行した, 前治療のないSCLC 94例における 5 年以上生存例について検討した. Coxの比 例ハザードモデルによる多変量解析では臨床病期 $(\mathrm{LD} / \mathrm{ED})$, 血清 NSE, 血清 LDHが有 意な予後因子であった. また 5 年以上生存例は 5 例 ( $5.3 \%$ ) あり, 全例LDで, NSE, LDH は低值を示し，PSは 0 から 1 であった。また化療効果はCR 3 例, PR 1 例, NC 1 例 であった。
\end{abstract}

〔肺癌 33(7)：1011 1016，1993〕

Key words : Small cell lung cancer, Long-term survival, Prognostic factors,

Cox's proportional hazard model

\section{はじめに}

肺小細胞癌 (SCLC) は進行が極めて早く, 早 期から遠隔転移をきたしやすいため, 加療しな い症例の予後は極めて悪い. そのため外科的治 療の対象となる症例は少なく, 治療は多剂併用 化学療法と放射線療法が中心となっている。こ れらの内科的治療によって長期生存例も認めら れるようになってきているが, 奏効例において も再発する症例が多く ${ }^{1)}$, 現状では長期生存例 は少ない.しかしながら, SCLCは肺癌の中で最 も内科的治療に感受性が高く, その治療目標は 治癒もしくは長期生存を得ることにある。その ため我々は，長期生存に必要な予後因子の同定 を目的として，当科において入院加療を行った SCLC, 特に 5 年以上生存例について retrospectiveに検討した。

兵庫医科大学第 3 内科

\section{対象および方法}

1978年から 1991年までの間に当科に入院し， 多剂併用化学療法を施行した，前治療のない SCLC 94例を対象とした，全例組織診あるいは 細胞診にて確定診断を得た症例である。

Table 1に患者背景を示す. 男性 68例, 女性 26 例で, 年齢の中央値は65.3歳 (57-73歳), Performance Status(PS) は $0-1$ が60例, 2 が18

Table 1. Patient characteristics.

\begin{tabular}{lll}
\hline Number of patients & & 94 \\
Sex (male/female) & & $68 / 26$ \\
Median age (range) & & $65(57-73)$ \\
Performance status & & \\
& $0-1$ & 60 \\
& 2 & 18 \\
& 3 & 13 \\
& 4 & 3 \\
Stage (LD/ED) & & $27 / 67$ \\
\hline
\end{tabular}


Table 2. Prognostic variables of SCLC.

\begin{tabular}{lc}
\hline Sex & male/female \\
Age & $<60 / \geqq 60$ \\
Predisposition to cancer & yes $/$ no \\
Smoking habit & yes $/$ no \\
Symptom & yes $/$ no \\
Complication & yes $/$ no \\
History of double cancer & yes $/$ no \\
Performance status & $0-1 / 2-4$ \\
Clinical stage & $\mathrm{LD} / \mathrm{ED}$ \\
PPD & positive/negative \\
TP & $<6.0 \mathrm{mg} / \mathrm{dl} / \geqq 6.0 \mathrm{mg} / \mathrm{dl}$ \\
LDH & $<400 \mathrm{IU} / 1 / \geqq 400 \mathrm{IU} / 1$ \\
WBC & $<8000 / \mu \mathrm{l} / \geqq 8000 / \mu 1$ \\
CEA & $<5.0 \mathrm{ng} / \mathrm{ml} \geqq 5.0 \mathrm{ng} / \mathrm{ml}$ \\
NSE & $<10.0 \mathrm{ng} / \mathrm{ml} / \geqq 10.0 \mathrm{ng} / \mathrm{ml}$ \\
\hline
\end{tabular}

例, 3 が13例， 4 が 3 例で, 臨床病期はLD 27 例，ED 67例であった。なお施行した化学療法の regimenは, Cyclophosphamide (CPM) + Adriamycin (ADM) + Vincristine (VCR), $A D M+$ Etoposide (VP16) + Cisplatin $(\mathrm{CDDP}), \mathrm{CDDP}+\mathrm{VP} 16$ 等である。病期分類と 抗腫瘍効果は日本肺癌学会の肺癌取扱規約 ${ }^{2}$ に 従って判定した.

検定した予後因子は 15 項目で，臨床的に妥当 と思われる区分に基づきカテゴリー化した (Table 2).生存期間は治療開始日より生死確認 日までとし，Kaplan-Meier法にて累積生存率 を算出し，一般化Wilcoxon法にて各カテゴリー 間の有意差検定を行った。また単変量解析にて 有意差を認めた因子に関しては，Coxの比例八 ザードモデルを用いて多変量解析を行った。以 上の統計処理は，べクセル社の医療統計用ソフ ト，ベクセル・マーク IIを用いた。

\section{結 果}

1) 生存率 (Fig. 1)

全対象94例の生存期間中央值 (MST) は238日 で，1，2，3 年生存率はそれぞれ $27.7,8.5,5.3$ \%であった。また 5 年以上生存例は 5 例, $5.3 \%$ であった。

\section{2 ) 予後因子の解析}

予後因子15項目について一般化Wilcoxon法
Fig. 1. Survival curve of 94 patients with SCLC.

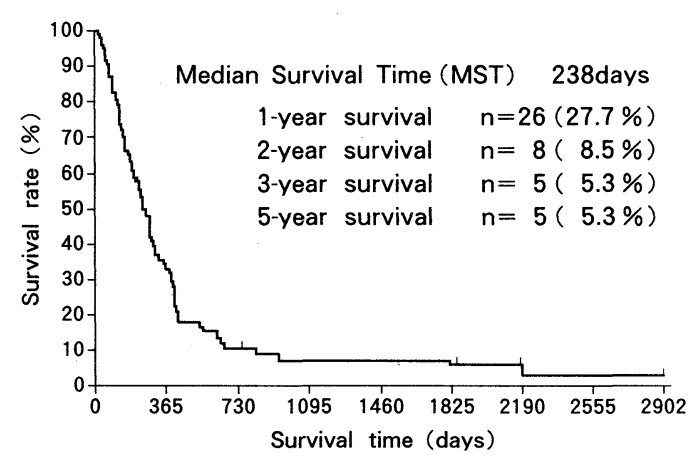

Table 3. Results of generalized Wilcoxon analysis of 94 patients with SCLC.

\begin{tabular}{ll}
\hline \multicolumn{1}{c}{ Variable } & $\mathrm{p}$ value \\
\hline PS & $<0.001$ \\
Clinical stage & $<0.001$ \\
LDH & $<0.001$ \\
WBC & $<0.01$ \\
NSE & $<0.05$ \\
\hline
\end{tabular}

Table 4. Result of Cox's proportional hazards regression analysis of 94 patients with SCLC.

\begin{tabular}{lc}
\hline \multicolumn{1}{c}{ Variable } & $\mathrm{p}$ value \\
\hline Clinical stage & $<0.001$ \\
NSE & $<0.01$ \\
LDH & $<0.01$ \\
WBC & 0.053 \\
PS & 0.148 \\
\hline
\end{tabular}

にて生存率の検定を行った。15項目中有意差を 認めたものはPS, 病期 (LD/ED), 血清 $\mathrm{LDH}$, NSE, 白血球数の 5 項目であった (Table 3). さ らに，単変量解析にて有意差を認めた 5 項目に ついて，Coxの比例ハザードモデルを用いて多 変量解析を行った結果, 病期が最も強い予後因 子で，以下NSE，LDHの順で有意であった (Table 4)。また，NSEとLDHの間には相関関 係が認められた $(\mathrm{p}<0.01)$.

\section{3 ） 5 年以上生存例の検討}

症例 1 : 50歳, 男性. 契煙係数 900 . 労作時呼 吸困難で発症. 昭和 55 年 9 月に当科入院となる. 
Table 5. Summary of 5-year survivors among patients with small cell lung cancer.

\begin{tabular}{ccccccccccccc}
\hline No & Age & Sex & B. I. & PS & LD/ED & Stage & $\begin{array}{c}\text { LDH } \\
(\mathrm{IU} / \mathrm{l})\end{array}$ & $\begin{array}{c}\mathrm{NSE} \\
(\mathrm{ng} / \mathrm{ml})\end{array}$ & Chemotherapy & Effects & Radiotherapy & Survival \\
\hline 1 & 50 & M & 900 & 1 & LD & III A & 328 & $(-)$ & CPA + ADM + VCR & NC & $(-)$ & $5 \mathrm{y} 11 \mathrm{~m}$ \\
2 & 65 & M & 1350 & 0 & LD & II & 367 & 6.6 & CDDP + ADM + VP16 & CR & $(-)$ & $6 \mathrm{y} 9 \mathrm{~m}^{*}$ \\
3 & 64 & M & 1600 & 0 & LD & III A & 259 & 5.3 & CDDP + VP16 & PR & $(+)$ & $5 \mathrm{y}$ \\
4 & 66 & F & 1350 & 0 & LD & I & 169 & 5.1 & CPA + ADM + VCR & CR & $(+)$ & $7 \mathrm{y} 11 \mathrm{~m}$ \\
5 & 59 & F & 1200 & 1 & LD & III A & 315 & $(-)$ & CPA + ADM + VCR & CR & $(+)$ & $8 \mathrm{y} 4 \mathrm{~m}$ \\
\hline
\end{tabular}

* Patient is still alived in January 1993.

胸部 $\mathrm{X}$ 線写真上, 右肺門部に $20 \times 30 \mathrm{~mm}$ 大の腫 瘤影を認め，同部よりの気管支鏡下生検にて SCLCの診断を得た. T3N1M0 (stage III A,

LD), PS 1であった。9月18日よりCPA 1000 $\mathrm{mg}+\mathrm{ADM} 30 \mathrm{mg}+\mathrm{VCR} 1 \mathrm{mg} 3$ クール施行 したがNCであった．放射線療法は施行しなか った。昭和61年 9 月 13 日に肺炎で死亡するまで の 5 年11カ月の間, 著明な腫瘍の増大を認めな かった。

症例 $2 ： 65$ 歳, 男性. 喫煙係数 1350. 乾性咳嗽 で発症. 昭和 61 年 3 月 26 日に当科入院となる. 胸部 X線写真上, 左下肺野に $28 \times 24 \mathrm{~mm}$ 大の腫 瘤除影を認め, 左 $\mathrm{B}^{10}$ よりの気管支鏡下擦過細胞 診にてSCLCの診断を得た. T2N0M0 (stageII, LD), PS 0であった。 3 月28日よりCDDP 125 $\mathrm{mg}+\mathrm{ADM}$ 60mg + VP16 150mgを1 クール行 いCRとなった．放射線療法は施行しなかった。 以後再発はみられず， 6 年 9 力月を経過した平 成 5 年 1 月 10 日現在，生存中である.

症例 $3: 64$ 歳, 男性. 契煙係数 1600 . 乾性咳 嗽で発症. 昭和 60 年 6 月 5 日に当科入院となる. 胸部 X線写真上，左上肺野に $60 \times 45 \mathrm{~mm}$ 大の腫 瘤院影を認女, 同部よりの気管支鏡下生検にて SCLCの診断を得た。 T2N2M0 (stage III A, LD), PS 0であった。 6 月11日よりVP16 150 $\mathrm{mg} /$ day (day 1-3) + CDDP $120 \mathrm{mg}$ (day 4) 3 クール施行LPRとなった. 化学療法後, 原発巣 を中心に total 800cGyの放射線療法を施行し た. その後昭和 62 年 10 月に第 5 腰椎に再発を認 め再度化学療法を施行したが, 初回治療より 5 年を経過した平成 2 年 6 月 25 日に死亡した。 症例 4 : 66歳, 女性. 乫煙係数 1350 . 湿性咳
嗽で発症. 昭和58年 4 月 14 日当科に入院となる. 胸部 $\mathrm{X}$ 線写真上左下肺野に $25 \times 27 \mathrm{~mm}$ 大の腫瘤 陰影を認め, 同部よりの気管支鏡下擦過細胞診 にてSCLCの診断を得た. T1N0M0 (stage I, LD), PS 0であった. 5 月 2 日より $\mathrm{ADM} 40$ $\mathrm{mg}+\mathrm{CPA} 1000 \mathrm{mg}+\mathrm{VCR} 1 \mathrm{mg} 4$ クール, さ らに原発巣を中心に $4980 \mathrm{cGy}$ の放射線治療を施 行しCRとなった. その後disease freeの状態が 続いていたが, 平成元年12月に再発し, 初回治 療より 7 年を経過した平成 2 年 4 月 12 日死亡し た.

症例 $5 ： 59$ 歳, 女性. 契煙係数 1200 . 湿性咳 嗽, 血痰で発症. 昭和57年 12 月 20 日, 当科に入 院となる。胸部 X 線写真上, 右上肺野に $30 \times 32$ $\mathrm{mm}$ 大の腫瘤陰影を認め, 同部よりの気管支鏡 下擦過細胞診にてSCLCの診断を得た。 T3N2 M0 (stage IIIA, LD), PS 1であった。昭和58 年 1 月14日より $\mathrm{ADM} 40 \mathrm{mg}+\mathrm{CPA} 1000 \mathrm{mg}+$ VCR 1mg を 3 クール施行し, さらに原発巣に 5040cGyの放射線治療を施行しCRとなった。 8 年 4 力月を経過した平成 3 年 4 月 15 日までdisease freeで生存中であったが, 以後追跡不能と なった。

以上の症例の要約をTable 5に示す。男性 3 例, 女性 2 例で, 平均年齢は 62.3 歳であった. 全例がLDで, PSは 0 が 3 例, 1 が 2 例で, LDH は全例400IU/1以下であった。化療効果はCR 3 例, PR 1 例, NC 1 例で, 5 例中 3 例が化学 療法後, 原発巣に放射線治療を施行していた。 治療前の血清 NSEは測定し得た 3 例とも 10 $\mathrm{mg} / \mathrm{d} 1$ 以下であった。なお予防的全脳照射を施 行した症例はなかった. 


\section{考案}

近年の化学療法の進歩には著しいものがあり， 肺小細胞癌の治療成績も年々向上しつつあるが 未だ長期生存例は少ない. 本邦でのSCLCの 5 年生存率は久保田 ( $^{3)}$ が $4.9 \%$, 小野ら ${ }^{4)}$ が $6.0 \%$ と報告している.我々の検討でも $5.3 \%$ とほぼ同 率であり，再現性のあるものと思われた。

予後因子の解析をした報告は少なからず認め られるが，今回の検討では病期 $(\mathrm{LD} / \mathrm{ED})$, 血清 NSE, 血清LDHの 3 つの因子が有意であった. 諸家の報告によると, SCLCの最も重要な予後 因子は治療前のPSとしているものが多い5) 8). 我々の検討では, 単変量解析ではPSが有意であ ったが, 多変量解析では有意ではなかった。こ のことは大江ら ${ }^{9}$ が述べているように，全身状 態の良好な症例が多かったためなのか, あるい はPSの判定が多分に主観的判断によるもので あり，客観性に久けるものであることがその主 因であると思われた。

全身状態以外には，腫瘍の進展度，すなわち 病期および腫瘍量も子後に影響を及ばすと報告 されている9). 血清LDHは腫瘍量を反映してい ると考えられており， $\phi$ sterlind $^{10)}$ や蒲田 ${ }^{11)}$ も同 様に血清LDHが最も強い子後因子であったと 報告している。また腫痬マーカーの予後因子と しての有用性を示した報告もあり, Laberge ら ${ }^{12)}$ はCEAが，J あったと報告している。そのため我々は治療前 のCEAとNSEについて検討したところ，CEA は有意ではなかったが, NSEには有意性を認め な.SCLCにおけるNSEの腫瘍マーカーとして の有用性は既知の通りであり, 診断と治療経過 のモニタリングに広く用いられている. 有吉 ${ }^{13)}$ は, その上昇はNSE産生の腫瘍量と相関すると 述べており，今回の検討でもNSEとLDHの間 に相関関係を認めたことから，NSEも LDH同 様, 腫瘍量を反映しているものと考えられた.

当院での 5 年以上生存例をみると, 全例 70 歳 以下であり, PSは $0 \sim 1$, 病期は全例 LDで,
LDHは400IU/1未満であった。またNSEに関し ては治療前に測定し得た 3 例はいずれも $10 \mathrm{ng} /$ $\mathrm{ml}$ 以下であり, 化療効果では 3 例がCRで， 1 例 がPRであった。すなわち, 今回の検討で有意性 を認めた病期 (LD), 血清NSE低值, 血清LDH低 值の 3 項目をいずれも満たしており, 予後因子 としてかなり信頼性の高いものと思われた。

今回の検討では, 化学療法や放射線療法の効 果の有無につ林解析していない. 予後因子 とは一般に治療前の因子を指し，これらと一緒 に加療効果を多変量解析にかけることに問題が あると思われるからである。しかしながら SCLCにおいて治療効果が予後に影響を与える ことはすでに明白であり，また今回の 5 年以上 生存例の分析においても CR例が多かったこと から, 今回有意であった病期, NSE, LDHが良 好な症例には積極的な治療を施し, CRにもって いくことが長期生存を得るために必要であると 思われた。

\section{まとめ}

1.1978年から1991年までの間に当科に入院し 多剂併用化学療法を受けた，前治療のない SCLC 94例を対象とした。内 5 年以上生存例は 5 例 (5.3\%)であった。

2 . 予後因子15項目の単変量解析では, PS, 臨 床病期, 血清NSE, 血清LDH, 白血球数に有意 差を認めた。

3. Coxの比例ハザードモデルを用いた多変量 解析では, 臨床病期, 血清NSE, 血清LDHの順 に有意であった。

4.SCLCで長期生存を得るためにはこれら の条件を満たした症例に対しては積極的な治療 を施し，CRにもっていくことが必要であると思 われた。

本論文の要旨は第32回日本肺癌学会総会 (1991年, 11 月, 大津) で発表した. 


\section{文献}

1) Vogelsang GB, Abeloff HD, Ettinger DS, et al : Long-term survivors of small cell carcinoma of the lung. Am J Med $79: 49-56$, 1985.

2) 日本肺癌学会編：肺癌取り扱い規約(第 3 版) 金原出版，18-20頁，122-123頁，1988.

3）久保田馨, 古瀬清行, 河原正明, 他：肺小細胞 癌における 7 例の 5 年生存例. 肺癌 $29: 133$ -139, 1989.

4）小野良祐, 柄川 順：非切除肺小細胞癌の 5 年 生存例の検討。日癌治 $23: 1491-1497,1988$,

5) Shinkai T, Sakurai M, Eguchi K, et al : Prognostic factor in small cell lung cancer : multivariate analysis in the national cancer hospital(Japan). Jpn J Clin Oncol $19: 135$, 1989.

6) Vincent MD, Ashley SE, Smith IE : Prognosis factor in small cell lung cancer : a simple prognostic index is better than conventional staging. Eur J Cancer Clin Oncol 23 : 1589, 1987.

7) Johnson BE, Steinberg SM, Phelps R, et al : Female patients with small cell lung cancer live longer than male patients. Am J Med $85: 194,1988$.

8) J $\phi$ rgensen LGM, $\phi$ sterlind K, Hansen HH, et al: The prognostic influence of serum neuron specific enolase in small cell lung cancer. Br J Cancer 58 : 805-807, 1988.

9）大江裕一郎, 西條長宏 : 予後因子解析の問題 点. 臨床医 $16: 70-72,1990$.

10) $\phi$ sterlind K \& Andersen PK : Prognostic factors in small cell lung cancer : Multivariate model based 778 patients treated with chemotherapy with or without irradiation. Cancer Res $46: 4189-4194,1986$.

11）蒲田淳夫：切除不能肺癌の予後因子. 癌と化学 療法 15(7)：2035-2042， 1988.

12) Laberge F, Fritsche HA, Umsawaadi $T$, et al: Use of carcinoembryonic antigen in small cell lung cancer. Cancer $59: 2047-2052$, 1987.

13）有吉 寛：肺癌の新しい腫瘍マーカーNeuron-specific Enolaseの意義. 癌の臨床 30 (6)： 569-573, 1984. 


\title{
Analysis of Prognostic Factors of Patients with Small Cell Lung Cancer using Cox's Proportional Hazards Model
}

\author{
Masahiko Takenaka, Noriaki Iwahashi, Takashi Nakano, \\ Juichiro Maeda, Nobuyuki Aihara, Yoshiki Amuro, \\ Toshikazu Hada and Kazuya Higashino
}

Third Department of Internal Medicine, Hyogo College of Medicine

A retrospective study on the five-year survival of 94 small cell lung cancer (SCLC) patients who had been treated with combination chemotherapy at Hyogo Medical College Hospital from 1978 to 1991 was carried out to identify factors which had prognostic significance for long-term survival. Prognosis was found to be significantly correlated with clinical stage (LD/ED), serum levels of NSE and LDH by multivariate analysis using Cox's proportional hazards model. Among these 94 cases, 5 (5.3\%) survived more than 5 years. All of these had limited disease, normal serum NSE and LDH level and good performance status. Moreover, the chemotherapeutic response of these 5 patients was as follows; complete remission in 3 , partial remission and no change in 1 each, respectively. 